\title{
Prevalence of HCV infection and associated factors among illicit drug users in Breves, State of Pará, Northern Brazil
}

\author{
Suzy Danielly Barbosa Pacheco ${ }^{[1]}$, Gláucia Caroline Silva-Oliveira ${ }^{[1],[5],}$ \\ Luciana Maria Cunha Maradei-Pereira ${ }^{[2]}$, José Ângelo Barletta Crescente ${ }^{[3]}$, \\ José Alexandre Rodrigues de Lemos $^{[2],[4]}$ and Aldemir Branco de Oliveira-Filho ${ }^{[2],[5]}$
}

[1]. Faculdade de Ciências Naturais, Campus do Marajó-Breves, Universidade Federal do Pará, Breves, PA. [2]. Centro de Hematologia e Hemoterapia do Pará, Belém, PA. [3]. Núcleo de Medicina Tropical, Universidade Federal do Pará, Belém, PA. [4]. Instituto de Ciências Biológicas, Universidade Federal do Pará, Belém, PA. [5]. Instituto de Estudos Costeiros, Universidade Federal do Pará, Bragança, PA.

\begin{abstract}
Introduction: Illicit drug users (DUs) are vulnerable to hepatitis C virus (HCV) infection. The shared use of illicit drugs is the main method of HCV transmission. Methods: A cross-sectional study was conducted in Breves, in northern Brazil. We surveyed 187 DUs to determine the prevalence of and factors associated with HCV infection. Results: The prevalence of anti-HCV antibodies was $36.9 \%$, and the prevalence of hepatitis $\mathrm{C}$ virus-ribonucleic acid (HCV-RNA) was $31 \%$. Hepatitis $\mathrm{C}$ virus infection was associated with tattoos, intravenous drug use, shared use of equipment for drug use, drug use for longer than 3 years, and daily drug use. Conclusions: Strategies for preventing and controlling HCV transmission should be implemented among DUs.
\end{abstract}

Keywords: Hepatitis C virus. Illicit drug users. Northern Brazil.

Currently, the sharing of drug paraphernalia is the main transmission method for hepatitis $\mathrm{C}$ virus (HCV) worldwide. It is estimated that more than $60 \%$ of new $\mathrm{HCV}$ infection cases recorded each year are related to the use of illicit drugs, particularly injected drugs ${ }^{1,2}$. In Brazil, epidemiological studies of HCV infection in illicit drug users are still rare. The prevalence of $\mathrm{HCV}$ infection in illicit drug users sampled in metropolitan areas in the Northeast, Midwest, South and Southeast regions of Brazil ranged from 5\% to $36 \%{ }^{3-7}$. There are frequent reports of clinical cases of hepatitis or pathologies associated with $\mathrm{HCV}$ infection in other population groups in northern Brazil ${ }^{8-11}$. It is known that most illicit drug users in Pará do not consume injected drugs and are infected with HCV genotype $1^{10,11}$. This study estimated the prevalence of HCV infection and assessed the factors associated with $\mathrm{HCV}$ infection in illicit drug users in the municipality of Breves, State of Pará, northern Brazil.

This cross-sectional study of a non-probabilistic convenience sample was based on information and biological samples provided by illicit drug users in an area of intense illicit drug use located in Breves ( $01^{\circ} 40^{\prime} 55^{\prime \prime} \mathrm{S} 50^{\circ} 28^{\prime} 48^{\prime \prime} \mathrm{O}$ ), Archipelago of Marajó, Pará, northern Brazil. Illicit drug users in areas of intense drug consumption were sampled using the snowball technique ${ }^{11}$. Individuals were eligible for the study if they were older than 17 years of age and agreed to answer a specific

Address to: Dr. Aldemir Branco Oliveira-Filho. Faculdade de Ciências Naturais, Instituto de Estudos Costeiros/UFPA. Al. Leandro Ribeiro, s/n. Aldeia, 68600000 Bragança, PA, Brasil.

Phone: 5591 3425-1593; Fax: 5591 3425-1209.

e-mail: olivfilho@ufpa.br

Received 21 July 2013

Accepted 27 November 2013 questionnaire and have a blood sample taken and tested for molecular and serologic markers in the period from August to December 2012. The Research and Ethics Committee of the Núcleo de Medicina Tropical of the Universidade Federal do Pará approved the study protocol (041/2004-CEP/NMT).

All samples were tested for HCV antibodies and hepatitis $\mathrm{C}$ virus-ribonucleic acid (HCV-RNA). Anti-HCV antibodies were tested by enzyme immunoassay (EIA; Murex anti-HCV 4.0, Murex Biotech). HCV RNA was detected by real-time polymerase chain reaction (PCR) using 67 base pairs of the 5' untranslated region (UTR), as described elsewhere'. Confidence intervals (CIs) were determined for infection prevalence estimates. Simple and multiple logistic regressions were calculated to assess the independent effects of variables ${ }^{12}$. The fit of the final model was assessed using the Hosmer-Lemeshow goodness-of-fit test. Two definitions of HCV infection were used: I) anti-HCV positivity shown by EIA, and II) HCV-RNA detection by real-time PCR. All statistical analyses were performed using IBM SPSS Statistics 18.

In total, 187 illicit drug users participated in this study. The majority of participants were male $(82.3 \%)$. The mean age was 28.5 years (range, $18-51$ years; standard deviation [SD] \pm 9.5 years). The majority of participants had $>7$ years of education $(55.6 \%)$ and belonged to families with monthly incomes of up to R $\$ 1,090.00$ (US\$545.00). Table 1 shows the demographic and epidemiological characteristics of the participants. In this study, most (78.1\%) participants reported having consumed more than one illicit drug during their lifetimes. Thus, illicit drug users were grouped according to the most frequently used drug. Drug preference was grouped into five categories: cannabis (21.9\%), cocaine paste $(20.9 \%)$, cannabis and cocaine paste (13.4\%), cocaine powder (18.2\%), and oxi cocaine (25.6\%). 
TABLE 1 - Demographic and epidemiological characteristics of illicit drug users in the municipality of Breves, State of Pará, northern Brazil.

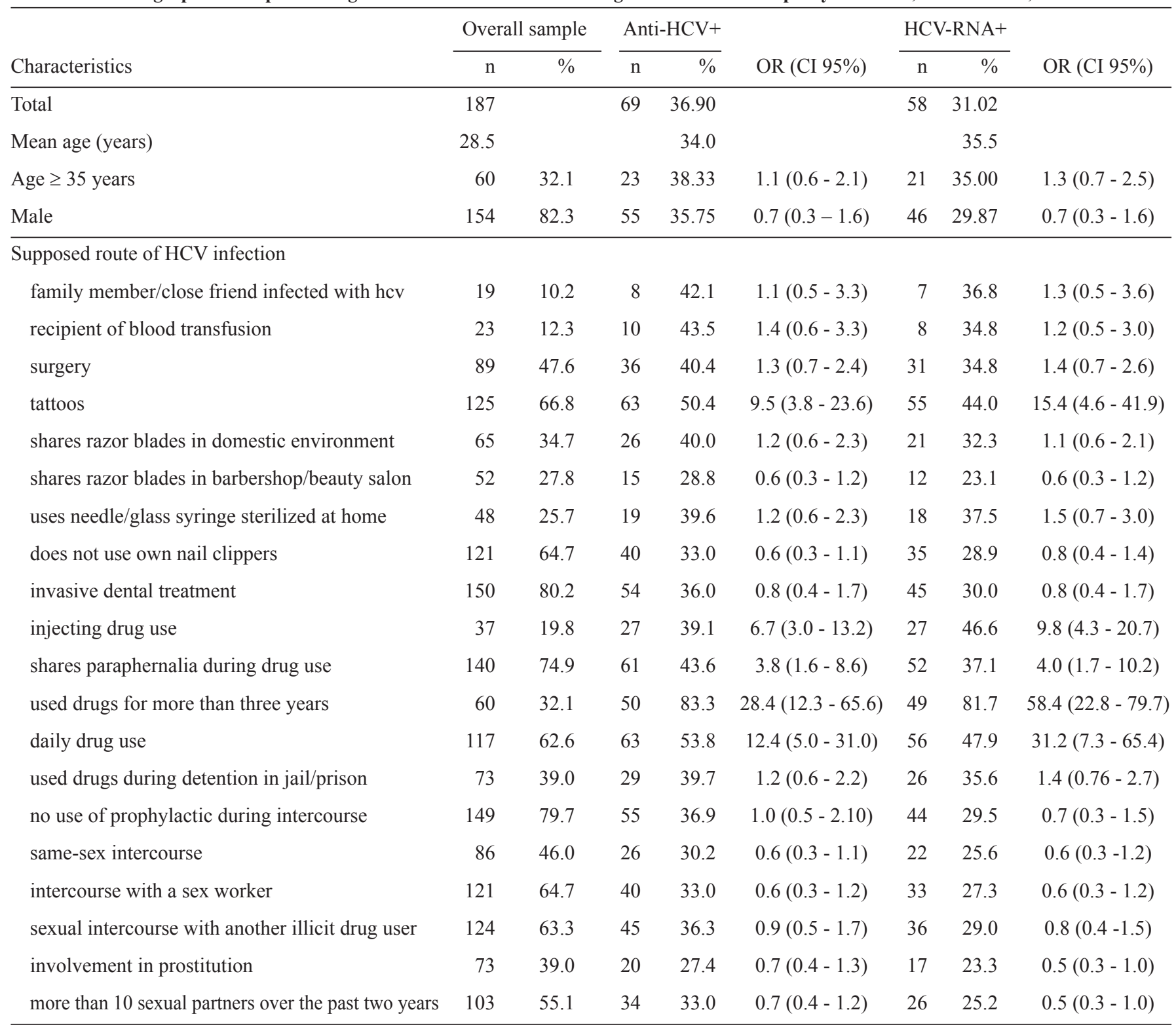

Note: A univariate analysis comparing the groups that tested positive and negative for HCV is presented through odds ratios and CIs. HCV-RNA: hepatitis C virus-ribonucleic acid; OR: odds ratio; CI: confidence interval.

All users reported a preference for using non-injected illicit drugs. However, 27 (14.4\%) users reported having used injected illicit drugs at least once. Tobacco $(64.7 \%)$ and alcohol $(87.7 \%)$ were also commonly consumed by the subjects.

Of the 187 illicit drug users, 69 (36.9\%) had anti-HCV antibodies, and 58 (31\%) had HCV-RNA. Using a simple logistic regression analysis, HCV infection was associated with tattoos, intravenous drug use, shared use of equipment for drug use, drug use for longer than 3 years, and daily drug use (Table 1). A multivariate analysis identified the same five risk factors for $\mathrm{HCV}$ infection for the two diagnostic methods employed (Table 2). The Hosmer-Lemeshow goodness-of-fit test showed a good fit for final model $1\left(_{\mathrm{HL}} \chi^{2}=3.8 ; \mathrm{p}=0.7\right)$ and model $2\left({ }_{\mathrm{HL}} \chi^{2}=2.7, \mathrm{p}=0.8\right)$.
Illicit drug users are currently the main group of people infected with hepatitis $\mathrm{C}^{1,13}$. It is well known that such individuals tend to develop a chronic infection, ultimately leading to chronic hepatitis. Many of these individuals are not clinically ill and are, therefore, unaware of their infection, leading to activities that contribute to an increased incidence of $\mathrm{HCV}^{2,15}$. The prevalence of HCV infection in illicit drug users varies from $10 \%$ to $95 \%$, reflecting the presence or absence of specific risk factors, such as having a history of drug use, sharing drug paraphernalia (e.g., needles, syringes, pipes, cans, etc.), tattooing, piercing the body/ears, using drugs while being detained in jail or prison, and the number of partners present during shared use and the method of drug consumption (i.e., inhaled or injected) $)^{1,4,5,13,15}$. 
TABLE 2 - Risk factors associated with HCV infection based on multiple logistic regression models.

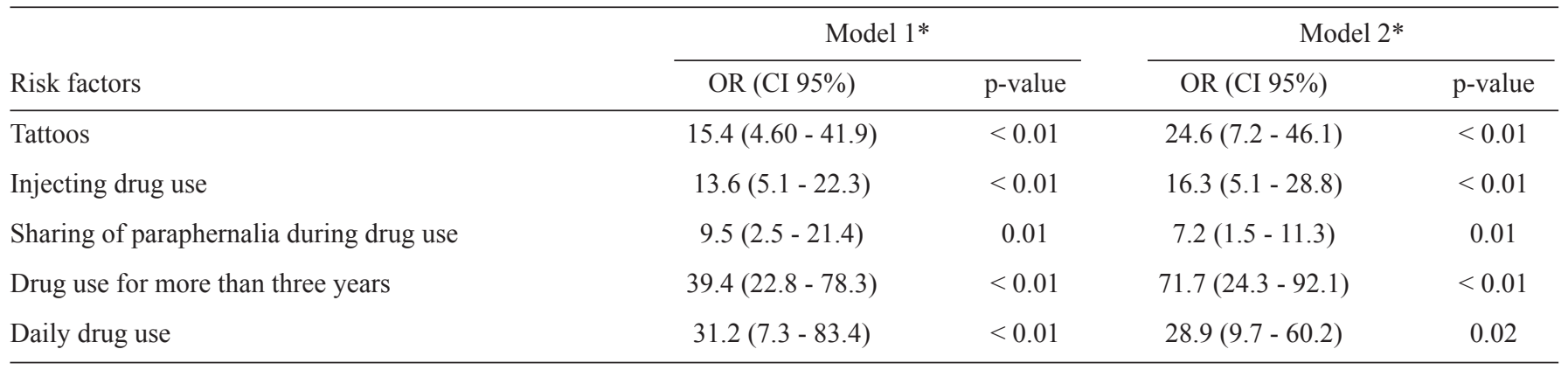

*HCV infection based on EIA (model 1) and PCR (model 2) results. HCV: hepatitis C virus; OR: odds ratio; CI: confidence interval; on EIA: enzyme immunoassay; PCR: polymerase chain reaction.

In Salvador (State of Bahia, northeastern Brazil) ${ }^{7}$, the seroprevalence of $\mathrm{HCV}$ infection detected in injected-drug users was similar to that observed in this study. Note that most of the study participants use non-injecting illicit drugs. The sporadic use of injectable illicit drugs, shared equipment for drug use, and daily drug use for more than three years most likely contribute significantly to viral transmission and a high prevalence of $\mathrm{HCV}$ infection among illicit drug users in the municipality of Breves. A few studies ${ }^{13,14}$ have reported the presence of HCV-RNA in the nasal secretions of cocaine and crack users, indicating a possible alternative route for virus transmission (i.e., sharing the paraphernalia used to consume these drugs).

The factors associated with $\mathrm{HCV}$ infection detected in illicit drug users in Breves are similar to those reported in epidemiological studies in different Brazilian municipalities for this risk group ${ }^{3-6,11}$. Specifically, the risk factors for HCV infection are identical to those detected in cocaine users in the State of Pará ${ }^{11}$, thus confirming the local epidemiological profile of HCV transmission in illicit drug users. In summary, this study identified important epidemiological aspects of $\mathrm{HCV}$ infection in illicit drug users in the municipality of Breves. The findings can be used to develop measures for controlling and preventing viral transmission in this risk group and in the general population.

\section{ACKNOWLEDGMENTS}

The authors thank the coordinators of the community centers in the different neighborhoods of the municipality of Breves. They contributed significantly to the collection of samples and epidemiological information from the illicit drug users.

\section{CONFLICT OF INTEREST}

The authors declare that there is no conflict of interest.

\section{FINANCIAL SUPPORT}

S.D.B. Pacheco received a scholarship from Programa Institucional de Bolsas de Iniciação Científica da Universidade
Federal do Pará (PIBIC/PROPESP/UFPA) for the development of this research. This study received financial support from Ministério da Saúde/Secretaria de Vigilância em Saúde (MS/SVS), Conselho Nacional de Desenvolvimento Cientifico e Tecnológico (CNPQ), and Programa de Apoio ao Recém Doutor da Universidade Federal do Pará (PARD-UFPA).

\section{REFERENCES}

1. Aceijas $\mathrm{C}$, Rhodes T. Global estimates of prevalence of HCV infection among injecting drug users. Int J Drug Policy 2007; 18:352-358.

2. Martins T, Narciso-Schiavon JL, Schiavon LL. Epidemiology of hepatitis C virus infection. Rev Assoc Med Bras 2011; 57:107-112.

3. Oliveira ML, Hacker MA, Oliveira SA, Telles PR, O KM, Yoshida CF, et al. "The first shot": the context of first injection of illicit drugs, ongoing injecting practices, and hepatitis $\mathrm{C}$ infection in Rio de Janeiro, Brazil. Cad Saude Publica 2006; 22:861-870.

4. Lopes CLR, Teles SA, Espírito-Santo MP, Lampe E, Rodrigues FP, Motta-Castro ARC, et al. Prevalence, risk factors and genotypes of hepatitis C virus infection among drug users, Central-Western Brazil. Rev Saude Publica 2009; 43:S1-S7.

5. Novais ACM, Lopes CLR, Reis NRS, Silva AMC, Martins RMB, Souto FJD. Prevalence of hepatitis $\mathrm{C}$ virus infection and associated factors among male illicit drug users in Cuiabá, Mato Grosso, Brazil. Mem Inst Oswaldo Cruz 2009; 104:892-896.

6. Oliveira ML, Bastos FI, Telles PR, Hacker MA, Oliveira SAN, Miguel JC, et al. Epidemiological and genetic analyses of Hepatitis C virus transmission among young/short- and long-term injecting drug users from Rio de Janeiro, Brazil. J Clin Virol 2009; 44:200-206.

7. Silva MB, Andrade TM, Silva LK, Rodart IF, Lopes GB, Carmo TMA, et al. Prevalence and genotypes of hepatitis $\mathrm{C}$ virus among injecting drug users from Salvador-BA, Brazil. Mem Inst Oswaldo Cruz 2010; 105: 299-303.

8. Torres KL, Malheiro A, Tateno A, Lima TA, Maia LPV, Pimentel JPD, et al. Hepatitis C vírus in blood donors, Brazil. Emerg Infect Dis 2009; 15:676-678.

9. Oliveira-Filho AB, Pimenta ASC, Rojas MFM, Chagas MCM, Crespo DM, Crescente JAB, et al. Prevalence and genotyping of hepatitis c virus in blood donors in the state of Pará, Northern Brazil. Mem Inst Oswaldo Cruz 2010; 105:103-106.

10. Sawada L, Pinheiro ACC, Locks D, Pimenta ASC, Rezende PR, Crespo DM, et al. Distribution of hepatitis $C$ virus genotypes among different exposure categories in the State of Pará, Brazilian Amazon. Rev Soc Bras Med Trop 2011; 44:8-12. 
11. Oliveira-Filho AB, Sawada L, Pinto LC, Locks D, Bahia SL, Brasil-Costa I, et al. HCV infection among cocaine users in the state of Pará, Brazilian Amazon. Arch Virol 2013; 158:1555-1560.

12. Oliveira-Filho AB, Pimenta ASC, Rojas MFM, Chagas MCM, Crespo DM, Crescente JAB, et al. Likely transmission of hepatitis $\mathrm{C}$ virus through sharing of cutting and perforating instruments in blood donors in the State of Pará, Northern Brazil. Cad Saude Publica 2010; 26:837-844.

13. Scheinmann R, Hagan H, Lelutiu-Weinberger C, Stern R, Des Jarlais DC, Flom PL, et al. Non-injection drug use and Hepatitis C Virus: a systematic review. Drug Alcohol Depend 2007; 89:1-12.
14. Aaron S, McMahon JM, Milano D, Torres L, Clatts M, Tortu S, et al. Intranasal Transmission of Hepatitis C Virus: Virological and Clinical Evidence. Clin Infect Dis 2008; 47:931-934.

15. Te HS, Jensen DM. Epidemiology of hepatitis B and C viruses: a global overview. Clin Liver Dis 2010;14:1-21. 